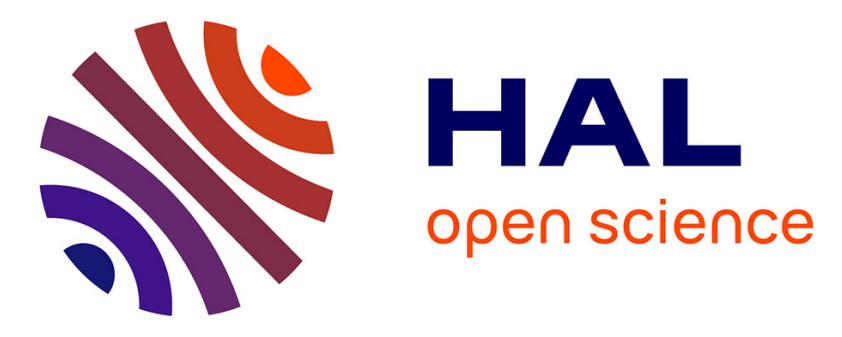

\title{
Kinetic degradation of amoxicillin by using the electro-Fenton process in the presence of a graphite rods from used batteries
}

Hakima Kadji, Idris Yahiaoui, Zehira Garti, Abdeltif Amrane, Farida Aissani-Benissad

\section{To cite this version:}

Hakima Kadji, Idris Yahiaoui, Zehira Garti, Abdeltif Amrane, Farida Aissani-Benissad. Kinetic degradation of amoxicillin by using the electro-Fenton process in the presence of a graphite rods from used batteries. Chinese Journal of Chemical Engineering, 2021, 32, pp.183-190. 10.1016/j.cjche.2020.08.032 . hal-03137412

HAL Id: hal-03137412

https://hal-univ-rennes1.archives-ouvertes.fr/hal-03137412

Submitted on 15 Feb 2021

HAL is a multi-disciplinary open access archive for the deposit and dissemination of scientific research documents, whether they are published or not. The documents may come from teaching and research institutions in France or abroad, or from public or private research centers.
L'archive ouverte pluridisciplinaire HAL, est destinée au dépôt et à la diffusion de documents scientifiques de niveau recherche, publiés ou non, émanant des établissements d'enseignement et de recherche français ou étrangers, des laboratoires publics ou privés. 
Article

Kinetic degradation of amoxicillin by using the electro-Fenton process in the presence of a graphite rods from used batteries

Hakima Kadji ${ }^{1, *}$, Idris Yahiaoui ${ }^{1}$, Zehira Garti $^{1}$, Abdeltif Amrane ${ }^{2}$, Farida Aissani-Benissad ${ }^{1}$

${ }^{1}$ Laboratoire de Génie de l'Environnement (LGE), Faculté de Technologie, Université de Bejaia, Bejaia 06000, Algeria.

${ }^{2}$ Ecole Nationale Supérieure de Chimie de Rennes, Université Rennes1, CNRS, UMR 6226, 11 allée de Beaulieu, CS 50837, France.

tel. 00 (213)34215704. E-mail : hakima.kadji@univ-bejaia.dz

\begin{abstract}
This study reports the removal of amoxicillin (AMX) in aqueous media using the electro-Fenton process in the presence of a graphite cathode recovered from used batteries. The impact of the relevant parameters on the electro-Fenton process, namely the applied current intensity, the temperature, the initial concentration of AMX and the initial concentration of ferrous ions were investigated. The results showed that the optimal values were: $I=600 \mathrm{~mA}$, $T=25^{\circ} \mathrm{C},[\mathrm{AMX}]_{0}=0.082 \mathrm{mmol} \cdot \mathrm{L}^{-1}$ and $\left[\mathrm{Fe}^{2+}\right]=1 \mathrm{mmol} \cdot \mathrm{L}^{-1}$, leading to $95 \%$ degradation and $74 \%$ mineralization. The model parameters of AMX mineralization were determined using nonlinear methods, showing that it follows a pseudo-second-order kinetic. The Energy consumption (EC) calculated under the optimal values was found to be $0.79 \mathrm{~kW} \cdot \mathrm{h}^{-1} \cdot \mathrm{g}^{-1}$, which was of the same order of magnitude of those reported in other findings; while it is noteworthy that the electrodes used in our study are of a lower cost.
\end{abstract}

Keywords: Wastewater, Amoxicillin, Electro-Fenton, Pharmaceuticals, Solid waste recovery, Kinetic modelling.

(C) 2020 The Chemical Industry and Engineering Society of China, and Chemical Industry Press Co., Ltd.. All rights reserved. 


\section{Introduction}

Industrial development and population growth has led to the use of many toxic chemicals. Every day a wide range of pharmaceutical products and pesticides are released into the environment [1]; they are detected at concentrations ranging from $n g \cdot \mathrm{L}^{-1}$ to $\mu \mathrm{g} \cdot \mathrm{L}^{-1}$ in wastewater, surface water, groundwater and treated drinking water [1, 2]. Research has shown various 
ecotoxicological effects of pharmaceutical products and pesticides. Godoy et al. [3] showed for example that antihypertensive drugs lead to larvae mortality and growth inhibition in fish and algae, respectively. Antibiotics affect bacterial community structures, modify bacterial ecology, and particularly of interest to public health lead to the development of resistant bacterial strains, posing treatment challenges when transferred to human systems [4].

Organic compounds can be removed from aqueous media by using various conventional methods, such as filtration, adsorption, membrane filtration, coagulation, flocculation and biological treatment [5-8]. However, these techniques have some disadvantages such as incomplete removal, high-energy requirements, the production of toxic sludge, low efficiency, sensitive operating conditions and costly disposal [9-11].

Among these techniques, biological methods such as activated sludge process and anaerobic treatment, the most cost-effective for wastewater treatment, which are destructive and have been extensively studied, do not always appear relevant for the removal of recalcitrant compounds, owing to their low biodegradability [12]. To overcome these disadvantages, Advanced Oxidation processes (AOPs) based on the generation of highly oxidative hydroxyl radical $(\cdot \mathrm{OH})$, can be considered for the removal of non-biodegradable pollutants from wastewater [13,14]. Aissani et al. [15] have studied the degradation of sulfamethazine by a photocatalytic process followed by a biological treatment; they obtained 58\% COD removal. Guerra et al. [16] have investigated the degradation of paracetamol and amoxicillin, the same removal yield 90\% was obtained for both paracetamol and amoxicillin. Annabi et al. [17] reported that an almost complete degradation of enoxacin was attained by the electro-Fenton process. Similar studies were carried out by Mojiri et al. [18] for the removal of antibiotics by ozone oxidation process; the degradation removal achieved were $84.8 \%$ and $82.7 \%$ for paracetamol and amoxicillin, respectively. The electro-Fenton process is one of the AOPs; it is an important and promising technology for wastewater treatment [19-23]. In this process $\mathrm{Fe}^{2+}$ 
is generated in situ by cathodic reduction of $\mathrm{Fe}^{3+}$ according to the reaction given by Eq. (1); hydrogen peroxide is produced in situ via equation 2 and then reacts with the $\mathrm{Fe}^{2+}$ to generate hydroxyl radicals $\left({ }^{\circ} \mathrm{OH}\right)$, according to Eq. (3). The three equations are given below [24-27]:

$$
\begin{aligned}
& \mathrm{Fe}^{3+}+\mathrm{e}^{-} \rightarrow \mathrm{Fe}^{2+} \\
& \mathrm{O}_{2}+2 \mathrm{H}^{+}+2 \mathrm{e}^{-} \rightarrow \mathrm{H}_{2} \mathrm{O}_{2} \\
& \mathrm{H}_{2} \mathrm{O}_{2}+\mathrm{Fe}^{2+} \rightarrow \mathrm{Fe}^{3+}+\mathrm{OH}+\mathrm{HO}^{-}
\end{aligned}
$$

This process allows the continuous generation of both $\mathrm{H}_{2} \mathrm{O}_{2}$ and $\mathrm{Fe}^{2+}$ ions at the cathode [Eq. (1) and Eq. (2)], which thus makes it possible to control the formation of $(\cdot \mathrm{OH})$ as a function of the Fenton reaction Eq. (3). The choice of the cathode type in the electro-Fenton process must meet the following conditions: i) a proper cathode material, ii) it should be able to produce $\mathrm{H}_{2} \mathrm{O}_{2}$ efficiently, iii) it should displays a low catalytic activity for its reduction and iv) a high potential for $\mathrm{H}_{2}$ evolution since the process is optimal in acid medium [28].

Batteries and accumulators are the most polluting materials among the wastes, since they contain many heavy metals (mercury, nickel, lithium, zinc, cadmium). When they end up in the food chain, following their dispersion in nature, heavy metals can be very toxic for humans, animals or nature. These heavy metals are very often carcinogenic and can cause allergies, reproductive disorders and neurotoxic effects. The percentage of batteries collected for recycling varies widely. Croatia, Slovakia, Switzerland and Belgium, for example, recycle more than $60 \%$ of them. In the European Union, the rate is as low as $45 \%$. The innovation of this study was to test the recycling of a part of the used battery, namely the graphite rods used as cathode material in the electro-Fenton process. This waste recycled as a cathode in the electro-Fenton process was tested for the degradation of amoxicillin (AMX), which belongs to a class of antibiotics called the penicillins ( $\beta$-lactam antibiotics)[29-32]. It is an antibiotic largely used in human medicine for the treatment and prevention of respiratory, gastrointestinal, urinary and skin bacterial infections. In addition, amoxicillin is commonly 
used in the veterinary field; it is very effective against animal diseases and it is also used as growth promoters for many domestic and food animal veterinary [30]. Human and animal body reject about $30 \%-90 \%$ of the given dose of antibiotic in its active form $[29,33]$, that is why the presence of amoxicillin in wastewater and even surface water is expected to be high [30]. Amoxicillin concentrations of $127.49 \mathrm{ng} \cdot \mathrm{L}^{-1}[34]$ and $84 \mu \mathrm{g} \cdot \mathrm{L}^{-1}$ [34] were found in wastewater effluent and hospital effluent were, respectively. The main objective of this study was to examine the removal of AMX from aqueous media using the electro-Fenton process in the presence of a graphite cathode recovered from used batteries. The influence of different experimental parameters on AMX kinetic degradation was studied, namely the current intensity, the temperature, the initial concentration of AMX and the initial concentration of ferrous ions.

\section{Materials and methods}

\subsection{Reagents}

The target compound was amoxicillin $\left(\mathrm{C}_{16} \mathrm{H}_{19} \mathrm{~N}_{3} \mathrm{O}_{5} \mathrm{~S}\right)$ with purity of $99 \%$.I It was purchased from Sigma; its characteristics are presented in Table $1 . \mathrm{Na}_{2} \mathrm{SO}_{4}\left(99 \%\right.$ purity), $\mathrm{H}_{2} \mathrm{SO}_{4}(96 \%$ purity), $\mathrm{FeSO}_{4} .7 \mathrm{H}_{2} \mathrm{O}$ (99 \% purity), $\mathrm{CH}_{3} \mathrm{OH}\left(99 \%\right.$ purity) and $\mathrm{KH}_{2} \mathrm{PO}_{4}(99.5 \%$ purity) were obtained from Biochem Chemopharma.

Table 1. Characteristics of amoxicillin

Chemical formula




\subsubsection{Electrodes}

The electrodes used in this study are presented in Figure 1. A graphite recovered from used batteries was used as cathode; it consisted of four cylinders of $12 \mathrm{~cm}^{2}$ area each one. stainless steel $304 \mathrm{~L}$ electrode $(50 \mathrm{~mm} \times 40 \mathrm{~mm} \times 1 \mathrm{~mm})$ was used as anode; its composition was $\mathrm{C} \leq 0.07$ $\%, \mathrm{Si} \leq 1 \%, \mathrm{Mn} \leq 2 \%, \mathrm{P}<0.045 \%, \mathrm{~S} \leq 0.015 \%, \mathrm{~N} \leq 0.1 \%, \mathrm{Cr}: 17$ to $19.5 \%, \mathrm{Ni}: 8$ to $10.5 \%$ and the balance being Fe iron.

\subsubsection{Experimental set-up}

The experimental set-up is described in Fig. 1; it mainly consisted of the following: (1): Temperature sensor, (2): DC supply (Model GW insTEK GPS-2303), (3): Graphite electrode (cathode), (4): stainless steel electrode (anode), (5): Magnetic stirrer, (6): air pump, and (7): solution of $\mathrm{H}_{2} \mathrm{SO}_{4}\left(1 \mathrm{~mol} \cdot \mathrm{L}^{-1}\right)$.

The experimental solution was prepared by diluting the AMX stock solution with distilled water. Electrolysis of aqueous solutions of AMX was carried out in one-compartment Pyrex glass cell. The total volume of Pyrex glass cell and the solution volume were 600 and $500 \mathrm{ml}$ respectively. 

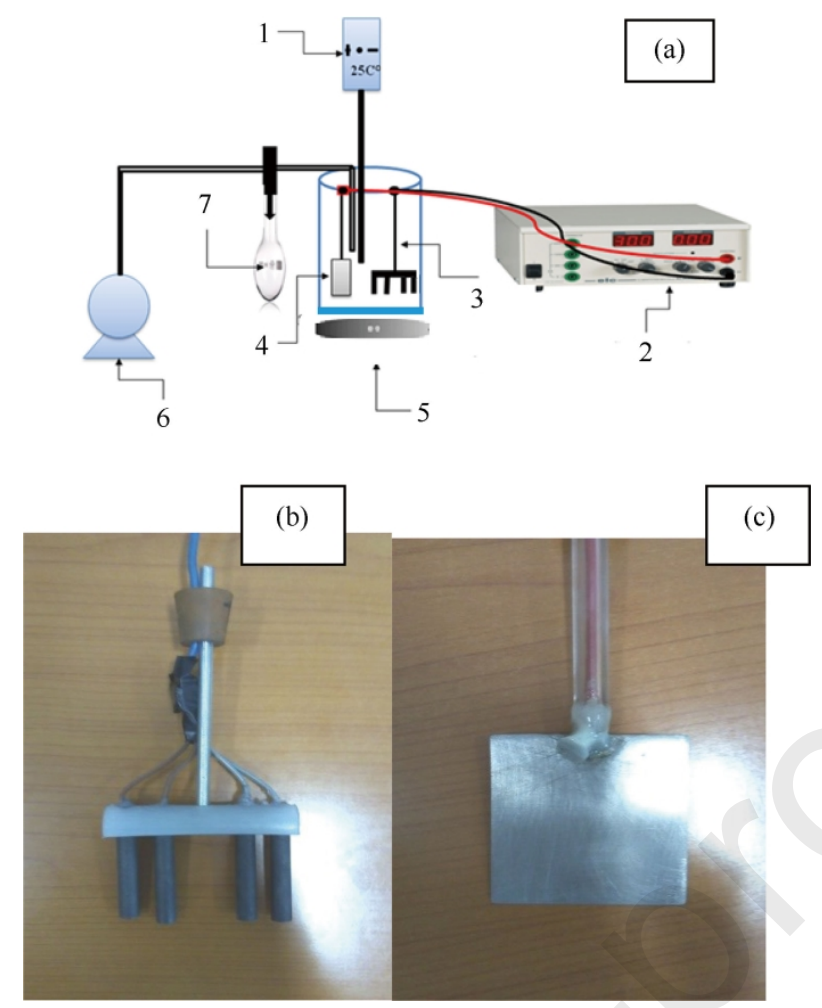

Fig. 1. Experimental: Experimental set up (a); Graphite cathode (b); Stainless steel anode (c)

\subsection{Analytical methods}

\subsubsection{Amoxicillin analysis}

The residual concentration of AMX was analyzed by High Performance Liquid Chromatography (HPLC ACC 3000 HPLC). The HPLC was equipped with a standard degasser (LPG 3400 SD), an autosampler. Pump (Model LPG 3400 SD) and a detector with visible ultraviolet ray (UV/ Vis detector VWD 3400 RS). The separation was achieved on a Thermo Fisher scientific (Germany) C18 $(5 \mathrm{~mm} ; 4.6 \times 150 \mathrm{~mm})$ reversed-phase column. The mobile phase consisted of $\mathrm{CH}_{3} \mathrm{OH} / \mathrm{KH}_{2} \mathrm{PO}_{4}(5 / 95 \mathrm{v} / \mathrm{v})$, the $\mathrm{KH}_{2} \mathrm{PO}_{4}$ concentration was $0.025 \mathrm{M}$ with a flow rate of $0.5 \mathrm{ml} \cdot \mathrm{min}^{-1}$ and the detection of AMX was carried out at $232 \mathrm{~nm}$.

\subsubsection{Dissolved organic carbon (DOC)}


Dissolved organic carbon (DOC) was measured by TOC-VCPH/CPN (Total Organic Analyzer

Schimadzu). Samples were taken and filtered through $0.22 \mu \mathrm{m}$ membrane syringe filter (Satorius Stedim biotech Gmbh,Germany) for the measurement of DOC [12,13,35,36].

\section{Theory calculation}

\subsection{Mineralization current efficiency}

The mineralization current efficiency (MCE) was calculated according to the Eq. (4) as follows $[13,37,38]:$

$\mathrm{MCE}=\frac{n F V \Delta(\mathrm{DOC})}{4.32 \times 10^{7} \mathrm{mIt}} 100 \%$

Where I/A is the current applied, $\mathrm{m}$ is the number of carbon of AMX, $4.32 \times 10^{7}$ is a conversion factor $\left(3600 \mathrm{~s} \cdot \mathrm{h}^{-1} \times 12,000 \mathrm{mg} \cdot \mathrm{mol}^{-1}\right.$ carbon $), t / \mathrm{h}$ a given electrolysis time, $\mathrm{n}$ the number of electrons required to oxidize one molecule of $\operatorname{AMX}\left(70 \mathrm{e}^{-}\right), F$ is the Faraday constant $(96487 \mathrm{C}$ $\mathrm{mol}^{-1}$ ), $V$ is the solution volume (L), (DOC) is the dissolved organic carbon.

The number of electrons $(n)$ was calculated for each experiment according to the following mineralization reaction of AMX Eq. (5):

$$
\mathrm{C}_{16} \mathrm{H}_{19} \mathrm{~N}_{3} \mathrm{O}_{5} \mathrm{~S}+31 \mathrm{H}_{2} \mathrm{O} \rightarrow 16 \mathrm{CO}_{2}+3 \mathrm{NH}_{4}^{+}+\mathrm{SO}_{4}^{2-}+69 \mathrm{H}^{+}+70 \mathrm{e}^{-}
$$

\subsection{Activation energy}

In order to assess the energy activation value $E_{\mathrm{a}}$ of the degradation reaction of AMX by the electro-Fenton process, we have to determine the slope of the straight line giving the logarithm 
of the apparent velocity constant $\left(\ln \left(k_{\text {app }}\right)\right.$ as a function of the inverse of the temperature $(1 / T)$, according to the Arrhenius law Eq. (6).

$$
k_{\text {app }}=A \exp ^{\frac{-E_{\mathrm{a}}}{R T}}
$$

Where: $A$ is the Arrhenius's constant; $E_{\mathrm{a}}$ is the apparent energy activation $\left(\mathrm{J} \cdot \mathrm{mol}^{-1}\right) ; T$ is the reaction temperature $(\mathrm{K}) ; R=8,314\left(\mathrm{~J} \cdot \mathrm{K}^{-1} \cdot \mathrm{mol}^{-1}\right)$.

\subsection{Kinetic study}

To define the kinetic model of the reaction of amoxicillin's degradation, first- Eq. (7) and second-order models Eq. (8) were tested.

$$
\begin{aligned}
& r=-\frac{\mathrm{d} C}{\mathrm{~d} t}=k_{1} C \\
& r=-\frac{\mathrm{d} C}{\mathrm{~d} t}=k_{2} C^{2}
\end{aligned}
$$

where: $C$ is the concentration of AMX at any time $\left(\mathrm{mg} \cdot \mathrm{L}^{-1}\right), r$ is the velocity of AMX degradation $\left(\mathrm{mg} \cdot \mathrm{L}^{-1} \cdot \mathrm{min}^{-1}\right), k_{1}\left(\mathrm{~min}^{-1}\right)$ and $k_{2}\left(\mathrm{~L} \cdot \mathrm{mg}^{-1} \cdot \mathrm{min}^{-1}\right)$ are the first-order and second order rate constants, respectively.

The integration of Eqs. (7) and (8) with the following initial conditions, $C / C_{0} \longrightarrow 0$ as $t \longrightarrow 0$ leads to:

$$
\begin{aligned}
& \frac{C}{C_{0}}=\exp \left(-t k_{1}\right) \\
& \frac{C}{C_{0}}=\frac{1}{1+t k_{2} C_{0}}
\end{aligned}
$$

The rate constants were calculated by minimizing the $D$ function Eq. (11) using the solver in Microsoft Excel [6,15].

$$
D=\sum_{i=1}^{p}\left(\left.\frac{C}{C_{0}}\right|_{\operatorname{Exp}}-\left.\frac{C}{C_{0}}\right|_{\text {Cal }}\right)^{2}
$$


Where: $P$ is the number of experimental data, $C_{0 \mathrm{Exp}}$ and $C_{0 \mathrm{Cal}}$ are the experimental and calculated data, respectively.

\subsection{Energy consumption}

Energy consumption (EC) is another parameter studied to evaluate the performance of the cathode related to the economic cost of the process. The EC for the electro-Fenton process is calculated as follows Eq. (12) [39] :

$$
\mathrm{EC}=\frac{1000 \text { UIt }}{\Delta \mathrm{DOC} V}
$$

Where: $U$ is the applied voltage $(\mathrm{V}), I$ is the current intensity (A), $t$ is the electrolysis duration (h), $\triangle \mathrm{DOC}$ is the removed DOC $\left(\mathrm{mg} \cdot \mathrm{L}^{-1}\right)$, and $V$ is the solution volume (L).

\section{Results and discussion}

\subsection{Effect of the applied current intensity}

The effect of the current intensity on the degradation of AMX was investigated. As shown in Fig. 2, the increase of the applied current intensity from 200 to $600 \mathrm{~mA}$ led to increasing the removal efficiency of AMX from 75\% to 95\% [Fig. 2(a)] and the mineralization yield from 45 to $74 \%$ [Fig. 2(b)] within $180 \mathrm{~min}$ of reaction time. This effect can be explained by an enhancement of the electron transfer on the cathode, which accelerates the formation of hydrogen peroxide according to equation 13 and the electro-generation rate of ferrous ions Eq. (14), which improves the generation of hydroxyl radicals.

$$
\begin{aligned}
& \mathrm{O}_{2}+2 \mathrm{H}^{+}+2 \mathrm{e}^{-} \rightarrow \mathrm{H}_{2} \mathrm{O}_{2} \\
& \mathrm{Fe}^{3+}+\mathrm{e}^{-} \rightarrow \mathrm{Fe}^{2+}
\end{aligned}
$$




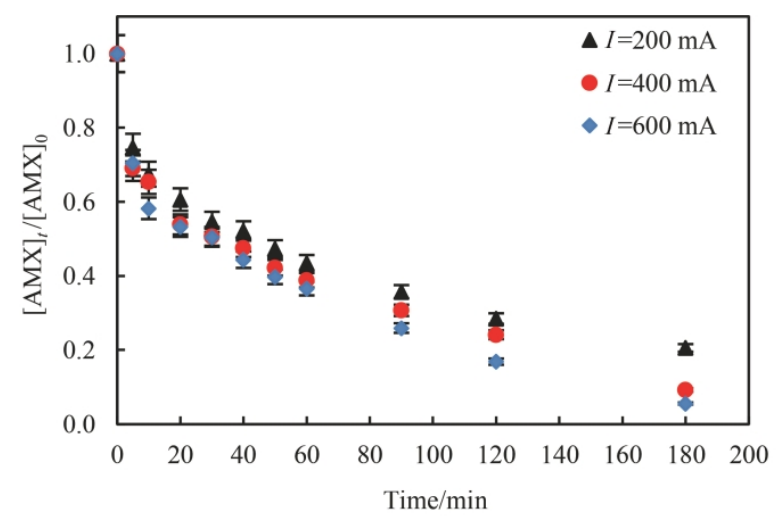

(a)

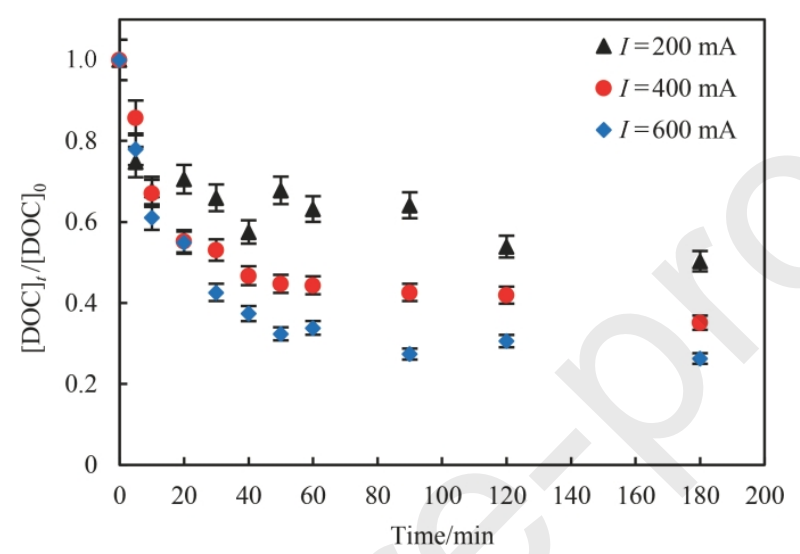

(b)

Fig.2. Influence of the current intensity on the degradation (a) and the mineralization (b) of AMX. Conditions : $[\mathrm{AMX}]_{0}=0.082 \mathrm{mM},\left[\mathrm{Fe}^{2+}\right]=2 \mathrm{mmol} \cdot \mathrm{L}^{-1},\left[\mathrm{Na}_{2} \mathrm{SO}_{4}\right]=50 \mathrm{mmol} \cdot \mathrm{L}^{-1}, \mathrm{pH}=3$, $T=25^{\circ} \mathrm{C}$, Agitation speed $(\omega) 360 \mathrm{r} \cdot \mathrm{min}^{-1}$.

\subsubsection{Mineralization current efficiency}

The yield of mineralization current efficiencies (MCE) versus the time of electrolysis during the mineralization of AMX is shown in Fig. 3. It is noteworthy that in Fig. 3, the MCE values always attained a maximum after 5 min electrolysis time; the rapid increase in MCE at the beginning of the experiments performed at 200, 400 and $600 \mathrm{~mA}$ suggested a rapid destruction of the products that are more easily oxidizable than the initial compound. Then, the MCE decreased progressively with the time of electrolysis due to the generation of byproducts more recalcitrant to oxidation than the AMX, such as carboxylic acids, as well as to the loss of organic matter, showing an increasing importance of wasting reactions [23]. The MCE was highly 
affected by the increase of the applied current, since the maximum MCE value was about 1.5 times higher at 200 and $400 \mathrm{~mA}$ than the corresponding value at $600 \mathrm{~mA}$. This effect is typical in electro advanced oxidation processes $[22,23]$ and is attributed to the increase in the rate of parasitic reactions.

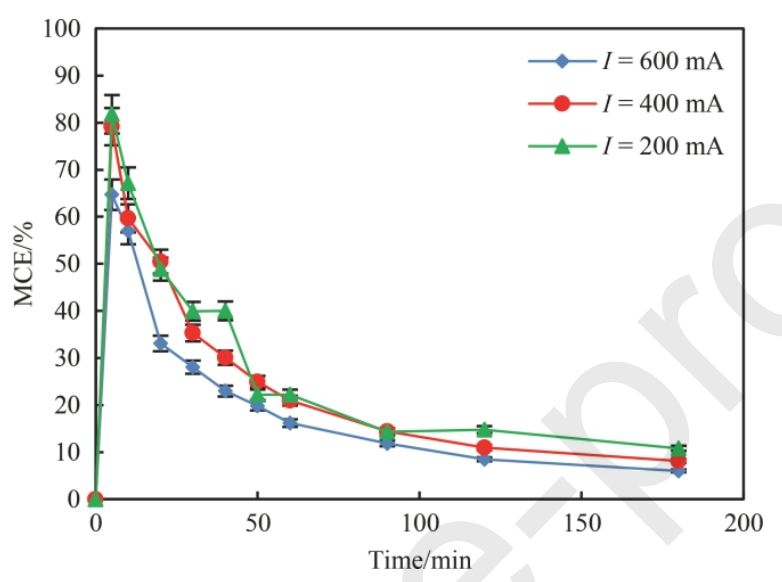

Fig. 3. Evolution of the mineralization current efficiency (MCE) during the degradation of the AMX. Conditions : $[\mathrm{AMX}]_{0}=0.082 \mathrm{mM},\left[\mathrm{Fe}^{2+}\right]=2 \mathrm{mmol} \cdot \mathrm{L}^{-1},\left[\mathrm{Na}_{2} \mathrm{SO}_{4}\right]=50 \mathrm{mmol} \cdot \mathrm{L}^{-1}, \mathrm{pH}=3$,

$$
T=25^{\circ} \mathrm{C}, \omega=360 \mathrm{r} \cdot \mathrm{min}^{-1} \text {. }
$$

\subsection{Effect of the temperature}

Experimental results of $\mathrm{AMX}$ degradation at various temperatures, namely, $25^{\circ} \mathrm{C}, 40^{\circ} \mathrm{C}$ and $60^{\circ} \mathrm{C}$ are displayed in Fig. 4. It is apparent that the degradation rate was favored by the temperature. The degradation efficiency within 120 min reaction time increased from $83.0 \%$ to $96.24 \%$ when the temperature increased from $25^{\circ} \mathrm{C}$ to $60^{\circ} \mathrm{C}$, respectively. Indeed, the solution temperature influences both electron transfer and mass transfer rates, and consequently, affects the regeneration rate of $\mathrm{Fe}^{2+}$. Within the same framework, Qiang et al. [40] and Mansour et al. [41] have proved that $\mathrm{Fe}^{2+}$ regeneration is favored at high temperatures. For an increase of the reaction time from $120 \mathrm{~min}$ to $180 \mathrm{~min}$, the AMX degradation rate increased only slightly with 
the temperature, and final mineralization yields were in the range $75 \%$ to $79 \%$ for the range of temperatures tested (Fig. 4). Consequently, the balance between the performances gain and the increase of the operating cost for an increase of the temperature led to select the lowest tested temperature, namely $25^{\circ} \mathrm{C}$ for the subsequent experiments.

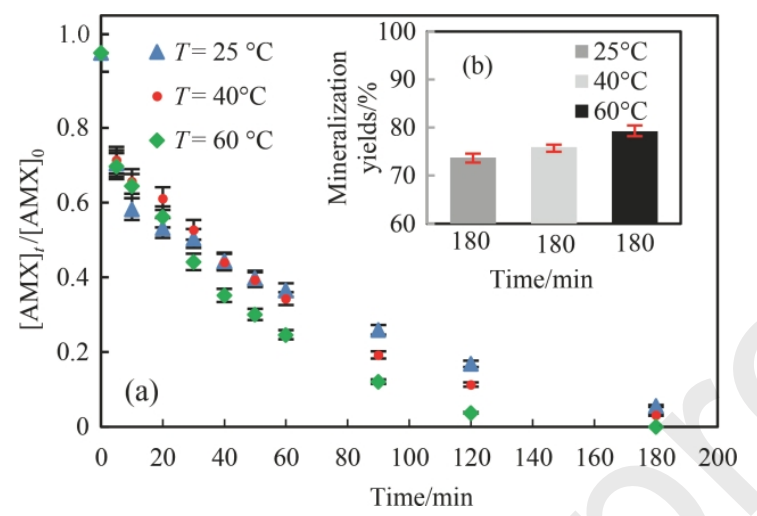

Fig. 4. Influence of the temperature on the degradation of AMX . Conditions : $I=600 \mathrm{~mA}$, $[A M X]_{0}=0.082 \mathrm{mmol} \cdot \mathrm{L}^{-1},\left[\mathrm{Na}_{2} \mathrm{SO}_{4}\right]=50 \mathrm{mmol} \cdot \mathrm{L}^{-1}, \mathrm{pH}=3,\left[\mathrm{Fe}^{2+}\right]=2 \mathrm{mmol} \cdot \mathrm{L}^{-1}, \omega=360 \mathrm{r} \cdot \mathrm{min}^{-1}$; (a) degradation of AMX; (b) mineralization of AMX.

The apparent energy activation can be calculated from the slope of the straight line of $\ln \left(\mathrm{k}_{\mathrm{app}}\right)$ versus $(1 / \mathrm{T})\left(\right.$ Fig. 5), giving a value of $13.15 \mathrm{~kJ} \cdot \mathrm{mol}^{-1}$. This allowed to conclude that it is lower than the activation energies reported in the literature by using other Advanced oxidation processes (AOPs) (Table 2).

The low value indicates that the degradation of AMX by electro-Fenton process requires relatively low activation energy and therefore can be easily achieved.

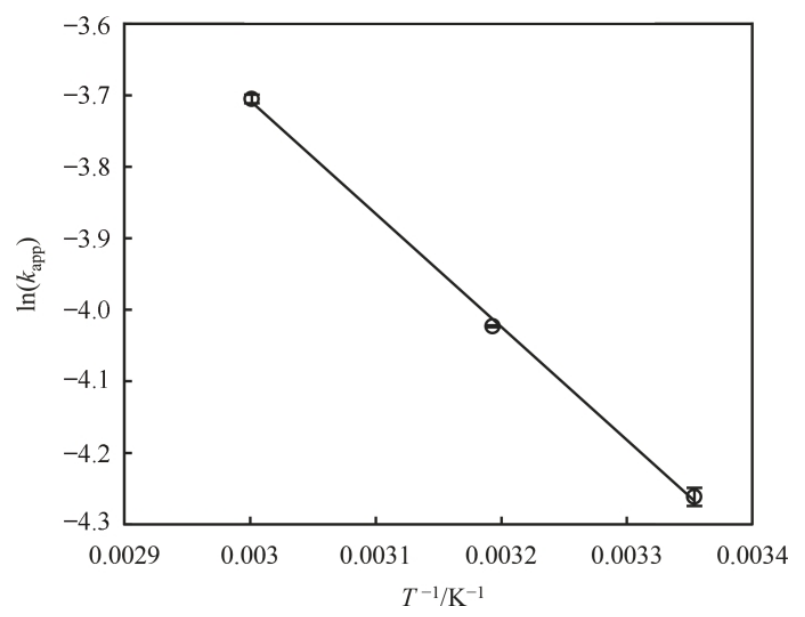


Fig. 5. The variation of $\ln k_{\text {app }}$ versus $1 / T$ for the degradation of AMX by the electro-Fenton process. Conditions: $I=600 \mathrm{~mA},[\mathrm{AMX}]_{0}=0.082 \mathrm{mmol} \cdot \mathrm{L}^{-1},\left[\mathrm{Na}_{2} \mathrm{SO}_{4}\right]=50 \mathrm{mmol} \cdot \mathrm{L}^{-1}, \mathrm{pH}=3 \omega=360$

$$
\mathrm{r} \cdot \min ^{-1}
$$

Table 2. Activation energy ( $E_{\mathrm{a}}$ ) of different Advanced oxidation processes (AOPs) for removal of organic compounds.

\begin{tabular}{cccc}
\hline Authors & Molecule studied & Initial concentration & Process \\
\hline Zhao et al., $2019[42]$ & Amoxicillin & $0.1 \mathrm{mmol} \cdot \mathrm{L}^{-1}$ & Thermally activated persulfate \\
\hline Li et al., $2019[43]$ & Norfloxacin & $20 \mathrm{mg} \cdot \mathrm{L}^{-1}$ & Peroxymonosulfate activation \\
\hline Norzaee et al., $2018[44]$ & Penicillin & $0.02 \mathrm{mmol} \cdot \mathrm{L}^{-1}$ & Peroxymonosulfate activation \\
\hline Milh et al., 2018 [45] & 4-Chlorophenol & $5000 \mathrm{mg} \cdot \mathrm{L}^{-1}$ & Microwave-Enhanced \\
\hline Present study & Amoxicillin & $0.082 \mathrm{mmol} \cdot \mathrm{L}^{-1}$ & Electro-Fenton \\
\hline
\end{tabular}

\subsection{Effect of the initial AMX concentration}

In order to investigate the effect of the initial concentration of AMX in the electro-Fenton process, experiments were carried out under the following conditions: $\left[\mathrm{Fe}^{2+}\right]=2 \mathrm{mmol} \cdot \mathrm{L}^{-1}, T=$ $25^{\circ} \mathrm{C}$ and $I=600 \mathrm{~mA}$, and two initial AMX concentrations were tested, 0.082 and 0.164 mmol $\cdot \mathrm{L}^{-1}$ [Fig. 6(a)]. Fig. 6(a), illustrates that the removal efficiency of AMX decreased for increasing initial concentration, from $95 \%$ to $85 \%$ when the initial concentration of AMX was increased from 0.082 to $0.164 \mathrm{mmol} \cdot \mathrm{L}^{-1}$. The same observation held true regarding the mineralization efficiency [Fig. 6(b)], since it decreased from $74 \%$ to $39 \%$ when the initial concentration of AMX was increased from 0.082 to $0.164 \mathrm{mmol} \cdot \mathrm{L}^{-1}$. This decrease in the removal and mineralization efficiencies was due to the constant amount of hydroxyl radicals irrespective of the initial AMX concentration and to a competitive consumption of oxidizing $\cdot \mathrm{OH}$ radicals between $\mathrm{AMX}$ and the by-products formed during experiment,s which increase with the initial AMX concentration. 


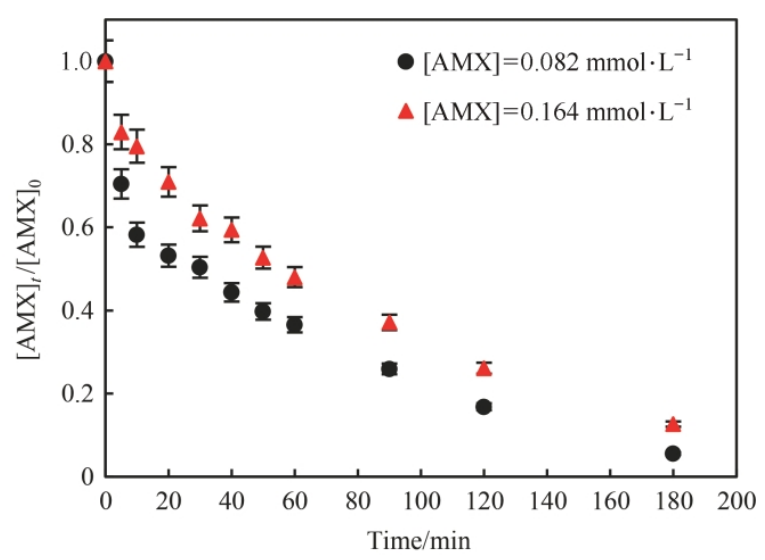

(a)

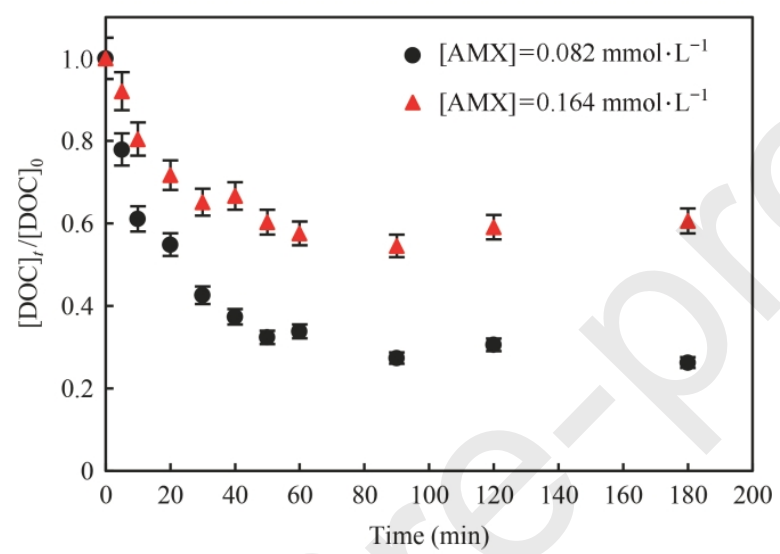

(b)

Fig. 6. Influence of the initial concentrations of the AMX on the degradation (a) and the mineralization of AMX. Conditions: $I=600 \mathrm{~mA},\left[\mathrm{Fe}^{2+}\right]=2 \mathrm{mmol} \cdot \mathrm{L}^{-1},\left[\mathrm{Na}_{2} \mathrm{SO}_{4}\right]=50 \mathrm{mmol} \cdot \mathrm{L}^{-1}$, $\mathrm{pH}=3, T=25^{\circ} \mathrm{C}, \omega=360 \mathrm{r} \cdot \mathrm{min}^{-1}$; (a) degradation of AMX; (b) mineralization of AMX.

\subsubsection{Kinetic study}

The kinetic model was determined by using the non-linear method; the obtained curves are presented in Figure 7. According to the obtained results (Fig. 7 and Table 3), the pseudo-second order kinetic model was the most appropriate to describe experimental data of AMX degradation. 


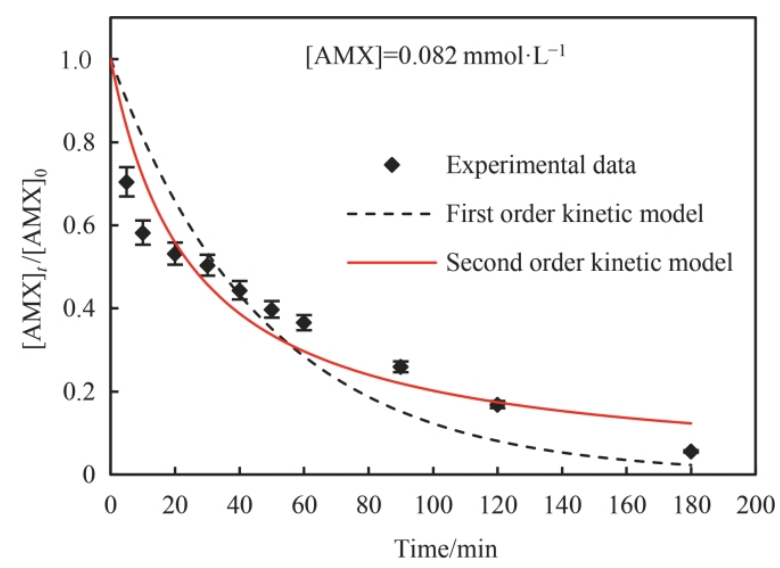

(a)

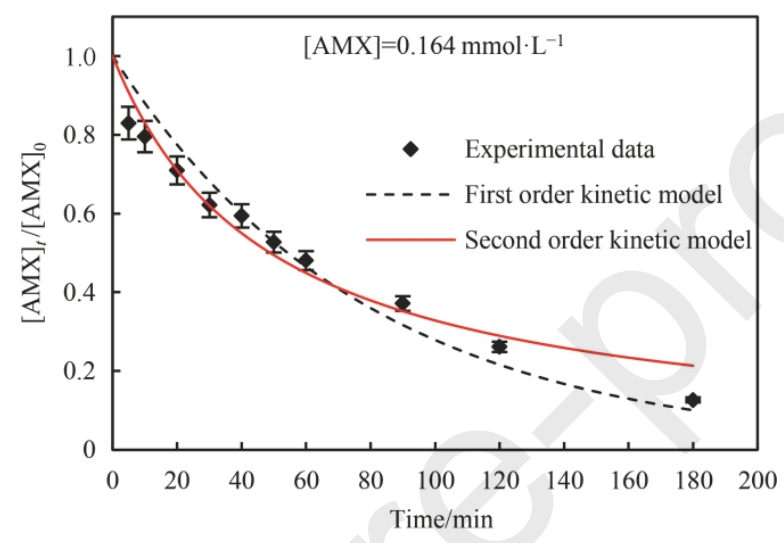

(b)

Fig. 7. Experimental data, first order kinetic model and second order kinetic model for the degradation of the AMX. Conditions: $I=600 \mathrm{~mA},\left[\mathrm{Fe}^{2+}\right]=2 \mathrm{mmol} \cdot \mathrm{L}^{-1},\left[\mathrm{Na}_{2} \mathrm{SO}_{4}\right]=50 \mathrm{mmol} \cdot \mathrm{L}^{-1}$,

$$
\mathrm{pH}=3, T=25^{\circ} \mathrm{C}, \omega=360 \mathrm{r} \cdot \mathrm{min}^{-1} \text {. }
$$

Table 3. Apparent rate constants, $D(\%)$ and $R^{2}$ values.

\begin{tabular}{|c|c|c|c|c|c|c|}
\hline \multirow{2}{*}{$\begin{array}{l}\text { Initial concentration of } \\
\qquad \mathrm{AMX} / \mathrm{mmol}^{-\mathrm{L}^{-1}}\end{array}$} & \multicolumn{3}{|c|}{ First-order kinetic model } & \multicolumn{3}{|c|}{ Second-order kinetic model } \\
\hline & $k_{2} / \min ^{-1}$ & $R^{2}$ & $\mathrm{D} / \%$ & $k_{1} / \mathrm{L} \cdot \mathrm{mg}^{-1} \cdot \mathrm{min}^{-1}$ & $R^{2}$ & $D / \%$ \\
\hline 0.082 & 0.0209 & 0.86 & 13.65 & $1.3810^{-3}$ & 0.90 & 5.5 \\
\hline 0.164 & $12.7710^{-3}$ & 0.96 & 3.27 & $3.610^{-4}$ & 0.96 & 1.9 \\
\hline
\end{tabular}

\subsection{Effect of the $\mathrm{Fe}^{2+}$ ions concentration}

Another important factor affecting the electro-Fenton process is the $\mathrm{Fe}^{2+}$ ions concentration. A series of experiments was therefore carried out to assess the optimal $\mathrm{Fe}^{2+}$ ions concentration by varying its concentration from 0.1 to $2 \mathrm{mmol} \cdot \mathrm{L}^{-1}$. According to the Fig. 8 (a), the $\mathrm{Fe}^{2+}$ ions concentration did not have a significant impact on the removal efficiency of AMX, while the 
effect of $\mathrm{Fe}^{2+}$ ions concentration on the mineralization yield was more pronounced. The results presented in Figure $8 \mathrm{~b}$ indicate that increasing the $\mathrm{Fe}^{2+}$ ions concentration from 0.1 to 1 $\mathrm{mmol} \cdot \mathrm{L}^{-1}$ increased the mineralization yield from $57 \%$ to $74 \%$ within 180 min of reaction; while further increase from 1 to $2 \mathrm{mmol} \cdot \mathrm{L}^{-1}$ did not improve the mineralization efficiency, which remained almost constant.

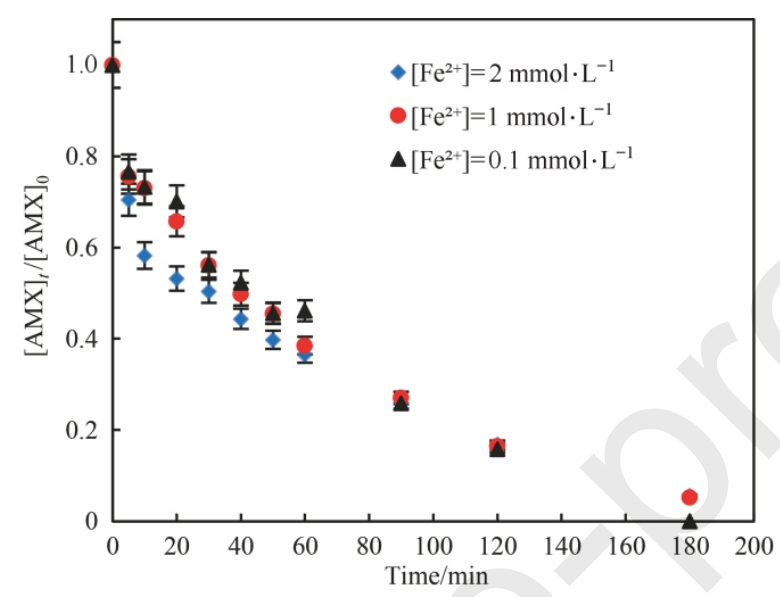

(a)

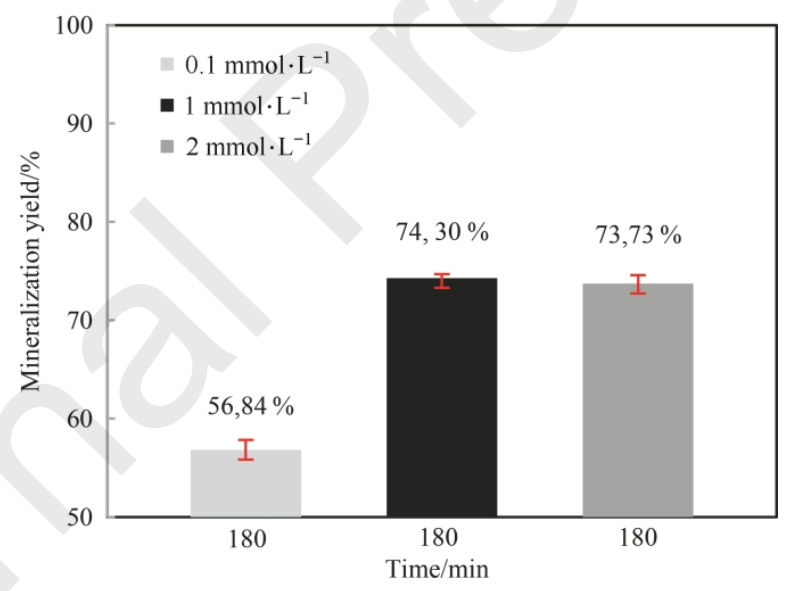

(b)

Fig. 8. Influence of the concentration of $\mathrm{Fe}^{2+}$ ions on the degradation of AMX.

Conditions: $I=600 \mathrm{~mA},[\mathrm{AMX}]_{0}=0.082 \mathrm{mmol} \cdot \mathrm{L}^{-1},\left[\mathrm{Na}_{2} \mathrm{SO}_{4}\right]=50 \mathrm{mmol} \cdot \mathrm{L}^{-1}, \mathrm{pH}=3, T=25^{\circ} \mathrm{C}, \omega=$ $360 \mathrm{r} \cdot \mathrm{min}^{-1}$. (a) degradation of AMX; (b) mineralization of AMX.

\section{Energy consumption}

The EC calculated under the optimal conditions: $I=600 \mathrm{~mA}, T=25^{\circ} \mathrm{C},[\mathrm{AMX}]_{0}=0.082$ $\mathrm{mmol} \cdot \mathrm{L}^{-1}$ and $\left[\mathrm{Fe}^{2+}\right]=1 \mathrm{mmol} \cdot \mathrm{L}^{-1}$, was found to be $0.79 \mathrm{~kW} \cdot \mathrm{h}^{-1} \cdot \mathrm{g}^{-1}$. Several works have been reported dealing with the electro-Fenton process for the removal of organic compounds from 
water $[22,46,47]$ they are compared to the results of the present work in Table 4 . The observed

EC was in the same range than those reported in other findings; while it is noteworthy that the electrodes used in our study are of a lower cost.

Table 4. Comparison of Energy consumption

\begin{tabular}{|c|c|c|c|c|}
\hline Authors & molecules studied & Type of processand electrodes used & Applied current $/ \mathrm{mA}$ & Energy consumption $/ \mathrm{kW} \cdot \mathrm{h}^{-1} \cdot \mathrm{g}^{-1}$ \\
\hline Oturan et al., 2017 [46] & Amoxicillin & $\begin{array}{c}\text { Electro-Fenton } \\
\text { Carbon felt as cathode and Boron Doped } \\
\text { Diamond (BDD) as anode }\end{array}$ & 120 & $>0.6$ \\
\hline Barhoumi et al., 2015 [22] & levofloxacin & $\begin{array}{c}\text { Electro-Fenton } \\
\text { Carbon felt as cathode and Boron Doped } \\
\text { Diamond (BDD) as anode. }\end{array}$ & 300 & $>3$ \\
\hline Mansour et al., 2014 [47] & Sulfamethazine & $\begin{array}{c}\text { Electro-Fenton } \\
\text { Carbon felt as cathode, platinum as anode. }\end{array}$ & 500 & 0.4 \\
\hline Present study & Amoxicillin & $\begin{array}{c}\text { Electro-Fenton } \\
\text { Graphite cathode recovered from used } \\
\text { batteries as cathode and stainless steel } 304 \mathrm{~L} \text { as } \\
\text { anode }\end{array}$ & 600 & 0.79 \\
\hline
\end{tabular}

\section{Conclusions}

In this study, the recycling of graphite rods from used batteries was successfully used as a cathode in the electro-Fenton process, which is influenced by several operating parameters, such the current density, the initial concentration of AMX, the temperature and the initial concentration of $\mathrm{Fe}^{2+}$ ions. It was demonstrated that the optimal values of the operating variables were: $[\mathrm{AMX}]_{0}=0.082 \mathrm{mmol} \cdot \mathrm{L}^{-1},\left[\mathrm{Fe}^{2+}\right]=1 \mathrm{mmol} \cdot \mathrm{L}^{-1}, I=600 \mathrm{~mA}$ and $T=25^{\circ} \mathrm{C}$, which led to $95 \%$ degradation and $74 \%$ mineralization yield of AMX. The kinetic model of the AMX degradation was determined using a non-linear method; based on the low $D(\%)$ values and the high $R^{2}$, the pseudo-second-order kinetics provided the most accurate fit of the experimental data. The Energy consumption calculated under the optimal values was found to be 0.79 $\mathrm{kW} \cdot \mathrm{h}^{-1} \cdot \mathrm{g}^{-1}$, which was in the same range than those reported in other findings.

\section{Nomenclature}

$\begin{array}{ll}\text { A } & \text { Arrhenius's constant } \\ \text { AMX } & \text { Amoxicillin }\end{array}$




\begin{tabular}{|c|c|}
\hline$[\mathrm{AMX}]_{0}$ & Initial concentration of $\mathrm{AMX}, \mathrm{mmol} \cdot \mathrm{L}^{-1}$ \\
\hline AOPs & Advanced Oxidation processes \\
\hline$C$ & Concentration of AMX at any time, $\mathrm{mg} \cdot \mathrm{L}^{-1}$ \\
\hline$C_{0}$ & Concentration of AMX at $t=0, \mathrm{mg} \cdot \mathrm{L}^{-1}$ \\
\hline$C_{0 \mathrm{Cal}}$ & Calculated data, $\mathrm{mg} \cdot \mathrm{L}^{-1}$ \\
\hline$C_{0 \text { Exp }}$ & Experimental data, $\mathrm{mg} \cdot \mathrm{L}^{-1}$ \\
\hline $\mathrm{COD} / \mathrm{O}_{2}$ & Chemical oxygen demand, $\mathrm{mg} \cdot \mathrm{L}^{-1}$ \\
\hline$D$ & Function of error, $\%$ \\
\hline DOC & Dissolved organic carbon, $\mathrm{mg} \cdot \mathrm{L}^{-1}$ \\
\hline$\triangle \mathrm{DOC}$ & Removed DOC, $\mathrm{mg} \cdot \mathrm{L}^{-1}$ \\
\hline$E_{\mathrm{a}}$ & apparent energy activation, $\mathrm{J} \cdot \mathrm{mol}^{-1}$ \\
\hline EC & Energy consumption \\
\hline$F$ & Faraday constant $(96487), \mathrm{C} \cdot \mathrm{mol}^{-1}$ \\
\hline$\left[\mathrm{Fe}^{2+}\right]$ & Initial concentration of $\mathrm{Fe}^{2+}, \mathrm{mmol} \cdot \mathrm{L}^{-1}$ \\
\hline$I$ & Applied current intensity, mA \\
\hline$k_{1}$ & First-order rate constant, $\min ^{-1}$ \\
\hline$k_{2}$ & Second-order rate constant, $\mathrm{L} \cdot \mathrm{mg}^{-1} \cdot \mathrm{min}^{-1}$ \\
\hline$k_{\text {app }}$ & Apparent rate constants, $\min ^{-1}$ \\
\hline$m$ & Number of carbon of AMX \\
\hline MCE & Mineralization current efficiency, $\%$ \\
\hline$n$ & Number of electrons \\
\hline$\cdot \mathrm{OH}$ & Hydroxyl radical \\
\hline$P$ & Number of experimental data \\
\hline$R$ & Universal constant $(8,314), \mathrm{J} \cdot \mathrm{mol}^{-1} \cdot \mathrm{K}^{-1}$ \\
\hline$t$ & Electrolysis time, $\min$ \\
\hline$T$ & Temperature, $^{\circ} \mathrm{C}$ \\
\hline$U$ & Applied voltage, $\mathrm{V}$ \\
\hline$V$ & Solution volume, $\mathrm{L}$ \\
\hline $4.32 \times 10^{7}$ & Conversion factor \\
\hline
\end{tabular}

\section{References}

[1] M.R. Khodadadi, S.H. Zolfani, M. Yazdani, E.K. Zavadskas, A hybrid MADM analysis in evaluating process of chemical wastewater purification regarding to advance oxidation processes, J. Environ. Eng. Landsc, 25 (3) (2017) 277-288. 
[2] K. O. K'oreje, M. Okoth, H. Van Langenhove, K. Demeestere, Occurrence and treatment of contaminants of emerging concern in the African aquatic environment: Literature review and a look ahead- a review, J. Environ. Manage, 254 (2020) 109752.

[3] A.A. Godoy, F. Kummrow, P.A.Z. Pamplin, Occurrence, ecotoxicological effects and risk assessment of antihypertensive pharmaceutical residues in the aquatic environment - A review. Chemosphere, 138 (2015) 281-291.

[4] P. Grenni, V. Ancona, A. Barra Caracciolo, Ecological effects of antibiotics on natural ecosystems-A review,

Microchem. J, 136 (2018) 25-39.

[5] S.S. Moghaddama, M.R. Alavi Moghaddama, M. Arami, Coagulation/flocculation process for dye removal using sludge from water treatment plant: Optimization through response surface methodology, J. Hazard. Mater, 175 (2010) 651-657.

[6] F. Boudrahem, F. Aissani-Benissad, A. Soualah, Removal of basic yellow dye from aqueous solutions by sorption onto reed as adsorbent,

Desalin. Water. Treat, 54 (6) (2015) 1727-1734.

[7] N. Boudrahem, S. Delpeux-Ouldriane, L. Khenniche, N. Boudrahem, F. Aissani-Benissad, M. Gineys, Single and mixture adsorption of clofibric acid, tetracycline and paracetamol onto Activated carbon developed from cotton cloth residue, Process. Saf. Environ, 111 (2017) 544-559.

[8] P.D. Amin, S. Joshi, V. Bhanushali, Advancements in technologies for water treatment, Int. J. Chemtech. Res, 11 (9) (2018). 260-276.

[9] H. Eccles, Treatment of metal-contaminated wastes: why select a biological process, Trends. Biotechnol, 17 (12) (1999) $462-465$.

[10] M.A. Barakat, New trends in removing heavy metals from industrial wastewater, Arab. J. Chem, 4 (4) (2011) 361-377.

[11] A.E. Burakov, E.V. Galunin, I.V. Burakov, A.E. Kucherova, S. Agarwal, A.G. Tkachev, V.K. Gupta, Adsorption of heavy metals on conventional and nanostructured materials for wastewater treatment purposes: A review, Ecotox. Environ. Safe, 148 (2018) 702-712.

[12] I. Yahiaoui, F. Aissani-Benissad, K. Madi, N. Benmehdi, F. Fourcade, A. Amrane, Electrochemical pre-treatment combined with biological treatment for the degradation of methylene blue dye: $\mathrm{Pb} / \mathrm{PbO}_{2}$ electrode and modeling-optimization through central composite design, Ind. Eng. Chem. Res, 52 (2013a) 14743-14751.

[13] A. Ledjeri, I. Yahiaoui, H. Kadji, F. Aissani-Benissad, A. Amrane, F. Fourcade, Combination of the Electro/ $\mathrm{Fe}^{3+} /$ peroxydisulfate (PDS) process with activated sludge culture for the degradation of sulfamethazine, Environ. Toxicol. Pharmacol, 53 (2017) 34-39. 
[14] I. Yahiaoui, L. Yahia Cherif, K. Madi, F. Aissani-Benissad, F. Fourcade, A. Amrane, The feasibility of combining an electrochemical treatment on a carbon felt electrode and a biological treatment for the degradation of tetracycline and tylosin —Application of the experimental design methodology, Sep. Sci. Technol, 53 (2018) 337-348.

[15] T. Aissani, I. Yahiaoui, F. Boudrahem, S. Ait Chikh, F. Aissani-Benissad, A. Amrane, The combination of photocatalysis process $\left(\mathrm{UV} / \mathrm{TiO}_{2}(\mathrm{P} 25)\right.$ and $\left.\mathrm{UV} / \mathrm{ZnO}\right)$ with activated sludge culture for the degradation of sulfamethazine, Sep. Sci. Technol, (2018) 1423-1433.

[16] M.M. Guerra Hinojosa, I. Oller Alberola, S. Malato Rodriguez, A. Agüera López, A. Acevedo Merino, J.M. Quiroga Alonso, Oxidation mechanisms of amoxicillin and paracetamol in the photo-Fenton solar process, Water. Res, 156 (2019) 232240.

[17] C. Annabi, F. Fourcade, I. Soutrel, F. Geneste, D. Floner, N. Bellakhal, A. Amrane, Degradation of enoxacin antibiotic by the electro-Fenton process: Optimization, biodegradability improvement and degradation mechanism, J. Environ. Manage, 165 (2016) 96-105

[18] A. Mojiri, M. Vakili, H. Farraji, S. Qarani Aziz, Combined ozone oxidation process and adsorption methods for the removal of acetaminophen and amoxicillin from aqueous solution; kinetic and optimisation, Environ. Technol. Innov, 15 (2019) 100-404.

[19] R. Munter, M. Trapido, Y. Veressinina, A. A. Goi, Cost effectiveness of ozonation and AOPs for aromatic compound removal from water: A preliminary study, Ozone Sci. Eng, 28 (5) (2006) 287-293.

[20] P. Canizares, M. Hernández-Ortega, M.A. Rodrigo, C.E. Barrera-Díaz, G. Roa-Morales, C.Sáez, A comparison between Conductive-Diamond Electrochemical Oxidation and other Advanced Oxidation Processes for the treatment of synthetic melanoidin, J. Hazard. Mater, 164 (2009) 120-125.

[21] M.A. Oturan, J.J. Aaron, Advanced Oxidation Processes in water/wastewater treatment: principles and applications. A Review, Crit. Rev. Env. Sci. Tec, 44 (23) (2014) 2577-2641.

[22] N. Barhoumi, L. Labiadh, M.A. Oturan, N. Oturan, A. Gadri, S. Ammar, E. Brillas, Electrochemical mineralization of the antibiotic levofloxacin by electro-Fenton-pyrite process, Chemosphere, 141 (2015) 250-257.

[23] C.N. Dominguez, N. Oturan, A. Romero, A. Santos, A. Mehmet, M.A. Oturan, Optimization of electro-Fenton process for effective degradation of organochlorine pesticide lindane, Catal. Today, 313 (2018) 196-202.

[24] N. Beqqal, M. Sh. Yahya, M.El Karbane, A. Guessous, K. El Kacemi, Kinetic study of the degradation/mineralization of aqueous solutions contaminated with Rosuvastatin drug by Electro-Fenton: Influence of experimental parameters, J.

Mater. Environ. Sci, 8 (12) (2017) 4399-4407. 
[25] X. Xu, G. Pliego, J.A Zazo, S. Sun, P. García-muñoz, L. He, J.A. Casas, J.J. Rodriguez, An overview on the application of advanced oxidation processes for the removal of naphthenic acids from water, Crit. Rev. Env. Sci. Tec, 47 (15) (2017) 1337-1370.

[26] O. Ganzenko, N. Oturan, I. Sires, D. Huguenot, E.D. van Hullebusch, G. Esposito, M.A. Oturan, Fast and complete removal of the 5-fluorouracil drug from water by electro-Fenton oxidation, ACS Med. Chem. Lett, 16 (1) (2018) 281-286.

[27] A. Aboudalle, F. Fourcade, A.A. Assadi, L. Domergue, H. Djelal, T. Lendormi, S. Taha, A. Amrane, Reactive oxygen and iron species monitoring to investigate the electro-Fenton performances. Impact of the electrochemical process on the biodegradability of metronidazole and its by-products, Chemosphere, 199 (2018) 486-494.

[28] H. Monteil, Y. Péchaud, N. Oturan, M.A. Oturan, A review on efficiency and cost effectiveness of electro- and bio-electrofenton processes: Application to the treatment of pharmaceutical pollutants in water, Chem. Eng. J, (2018)

[29] E.K. Putra, R. Pranowoa, J. Sunarso, N. Indraswati, S. Ismadji, Performance of activated carbon and bentonite for adsorption of amoxicillin from wastewater: Mechanisms, isotherms and kinetics, Water. Res, 43 (9) (2009) 2419-2430.

[30] A. Elizalde-Velázquez, L.M. Gómez-Oliván, M. Galar-Martínez, H. Islas-Flores, O. Dublán-García, N. SanJuan-Reyes, Amoxicillin in the aquatic environment, Its Fate and Environmental Risk Chapter 10, in IntechOpen (Eds.), Environmental Health Risk-Hazardous Factors to Living Species, (2016), pp. 247-267.

[31] B. Wang, M. Pang, X. Xie, M. Zhao, K. Xie, Y. Zhang, X. Zhao, Y. Wang, R.Wang, H. Wu, G. Zhang, G. Dai, J. Wang, Quantitative analysis of amoxicillin, amoxicillin major metabolites, and ampicillin in chicken tissues via ultra performance liquid chromatography-electrospray ionization tandem mass spectrometry, Food. Anal. Methods, 10 (2017) 3292-3305.

[32] J.B. Arsand, R.B. Hoff, L. Jank, L.N. Meirelles, M.S. Díaz-Cruz, T.M. Pizzolato, D. Barceló, Transformation products of amoxicillin and ampicillin after photolysis in aqueous matrices: Identification and kinetics, Sci. Total. Environ, 52 (11) (2018) 6476-6468.

[33] M. Velásquez, I. P. Santander, D.R. Contreras, J. Yáñez, C. Zaror, R.A. Salazar, M. Pérez-Moya, H.H. Mansilla, Oxidative degradation of sulfathiazole by Fenton and photo-Fenton reactions, J. Environ. Sci. Heal. A, 49 (6) (2014) 661-670.

[34] C. Kim, H.D. Ryu, E.G. Chung, Y. Kim, Determination of 18 veterinary antibiotics in environmental water using highperformance liquid chromatography-q-orbitrap combined with on-line solid-phase extraction, J. Chromatogr. B, 1084 (2018) 158-165.

[35] I. Yahiaoui, F. Aissani-Benissad, F. Fourcade, A. Amrane, Removal of a mixture tetracycline-tylosin from water based on anodic oxidation on a glassy carbon electrode coupled to activated sludge, Environ. Technol, 36 (14) (2015) 1837-1846. 
[36] I. Yahiaoui, F. Aissani-Benissad, F. Fourcade, A. Amrane, Combination of an electrochemical pre-treatment with a biological oxidation for the mineralization of nonbiodegradable organic dyes: basic yellow 28 dye, Environ. Prog. Sustain. Energy, 33 (2013b) 160-169.

[37] J. Meijide, J. Gómez, M. Pazos, M.A. Sanromán, Degradation of thiamethoxam by the synergetic effect between anodic oxidation and Fenton reactions, J. Hazard. Mater, 319 (2016) 43-50.

[38] D.A.C. Coledam, M.M.S. Pupo, B.F. Silva, A.J. Silva, K.I.B. Eguiluz, G.R. Salazar-Banda, J.M. Aquino, Electrochemical mineralization of cephalexin using a conductive diamond anode: A mechanistic and toxicity investigation, Chemosphere, 168 (2017) 638-647.

[39] Y. Zhang, S. Zuo, M. Zhou, L. Liang, G. Ren, Removal of tetracycline by coupling of flow-through electro-Fenton and in situ regenerative active carbon felt adsorption, Chem. Eng. J, 335 (2018) 685-692.

[40] D. Mansour, F. Fourcade, N. Bellakhal, M. Dachraoui, D. Hauchard, A. Amrane, Biodegradability improvement of sulfamethazine solutions by means of an electro-Fenton process, Water. Air. Soil. Pollut, 223 (2012) 2023-2034.

[41] Z. Qiang, J.H. Chang, C.P. Huang, Electrochemicalregeneration of $\mathrm{Fe}^{2+}$ in Fenton oxidation processes. Water. Res, 37 (2003) 1308-1319

[42] J. Zhao, Y. Sun, F. Wu, M. Shi, X. Liu, Oxidative degradation of amoxicillin in aqueous solution by thermally activated persulfate, J. Chem, (2019).

[43] J. Li, X. Li, X. Wang, L. Zeng, X. Chen, J. Mu, G. Chen, Multiple Regulations of Mn-based Oxides in Boosting Peroxymonosulfate Activation for Norfloxacin Removal, Appl. Catal. A-Gen, 584 (2019) 117170.

[44] S. Norzaee, M. Taghavi, B. Djahed, F.K. Mostafapour, Degradation of Penicillin G by heat activated persulfate in aqueous Solution, J. Environ. Manage, 215 (2018) 316-323.

[45] H. Milh, K. Van Eyck, R. Dewil, Degradation of 4-chlorophenol by microwave-enhanced advanced oxidation processes: Kinetics and influential process parameters, Water, 10 (2018) 247.

[46] N. Oturan, S.O. Ganiyu, S. Raffy, M.A. Oturan, Sub-stoichiometric titanium oxide as a new anode material for electroFenton process: Application to electrocatalytic destruction of antibiotic amoxicillin, Appl. Catal. B-Environ, 217 (2017) $214-$ 223.

[47] D. Mansour, F. Fourcade, S. Huguet, I. Soutrel, N. Bellakhal, M. Dachraoui, D. Hauchard, A. Amrane, Improvement of the activated sludge treatment by its combination with electro Fenton for the mineralization of sulfamethazine, Int. Biodeter. Biodegr, 88 (2014) 29-36. 
Graphical abstract
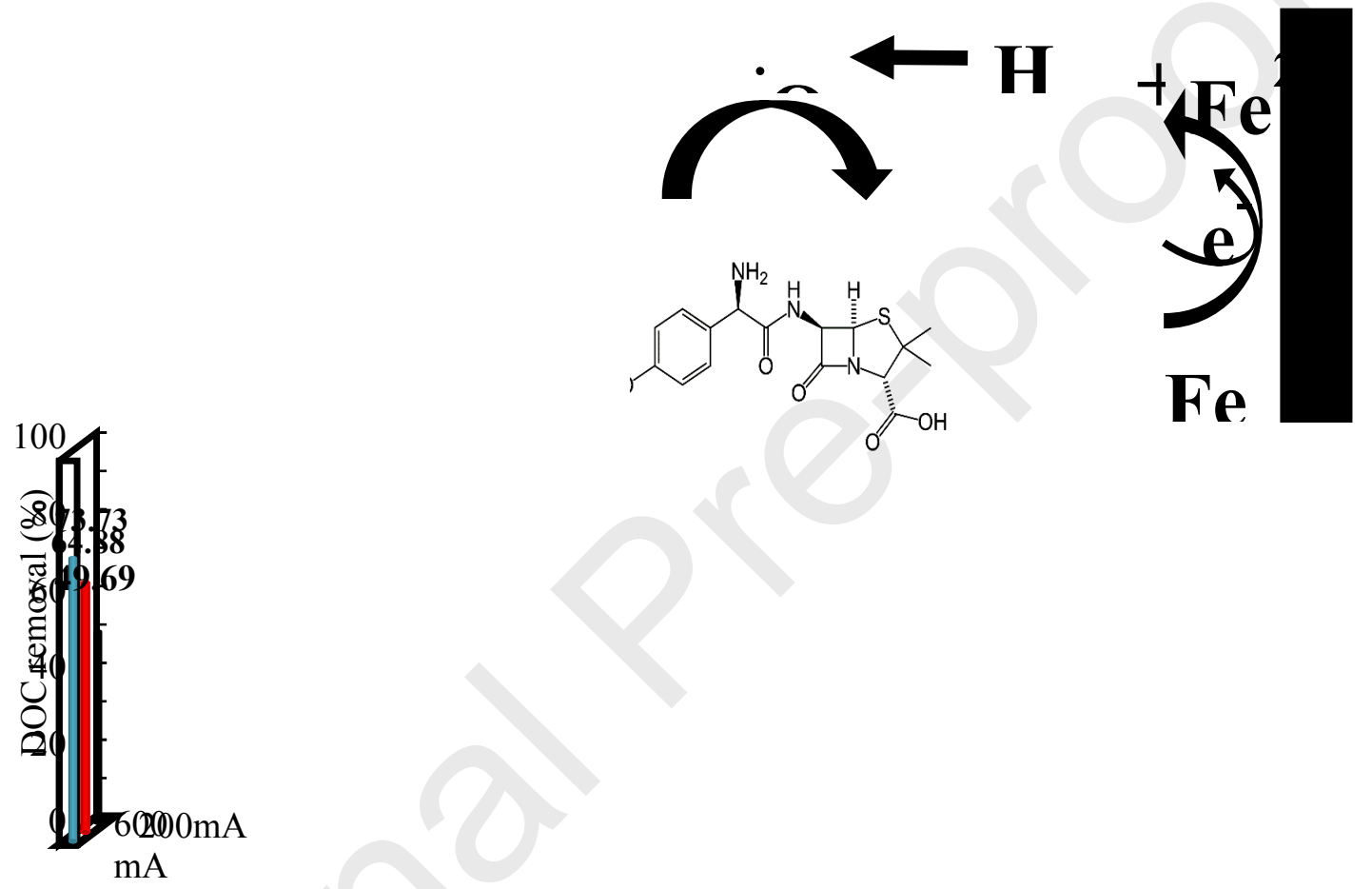
Declaration of interests

$x$ The authors declare that they have no known competing financial interests or personal relationships that could have appeared to influence the work reported in this paper.

$\square$ The authors declare the following financial interests/personal relationships which may be considered as potential competing interests: 